\title{
Frontières
}

\section{Le numéro de la Mort}

\section{Pascale Rafie}

Volume 18, numéro 1, automne 2005

Hélas, célébrer la mort!

URI : https://id.erudit.org/iderudit/1074322ar

DOI : https://doi.org/10.7202/1074322ar

Aller au sommaire du numéro

Éditeur(s)

Université du Québec à Montréal

ISSN

1180-3479 (imprimé)

1916-0976 (numérique)

Découvrir la revue

Citer ce document

Rafie, P. (2005). Le numéro de la Mort. Frontières, 18(1), 72-72.

https://doi.org/10.7202/1074322ar

Ce document est protégé par la loi sur le droit d'auteur. L'utilisation des services d'Érudit (y compris la reproduction) est assujettie à sa politique d'utilisation que vous pouvez consulter en ligne.

https://apropos.erudit.org/fr/usagers/politique-dutilisation/
Cet article est diffusé et préservé par Érudit.

Érudit est un consortium interuniversitaire sans but lucratif composé de l’Université de Montréal, l'Université Laval et l'Université du Québec à Montréal. Il a pour mission la promotion et la valorisation de la recherche. https://www.erudit.org/fr/ 


$\begin{array}{llllll}R & E & G & A & R & D\end{array}$

\section{LE NUMÉRO DE LA MORT \\ Pascale Rafie, auteure.}

\section{Scène 16, extraite de Le Paradis mobile, comédie candide}

Cette pièce relate la triste et joyeuse épopée de la Sainte et sensuelle Magda, 125 ans, dans un monde ravagé par la guerre. Après avoir conclu un pacte avec la Mort, elle part à la recherche de l'homme le plus malheureux de toute la Terre. Quand elle l'aura trouvé et qu'elle aura fait l'amour avec lui, la guerre disparaîtra, croit-elle - et peut-être que la Mort elle-même rendra les armes. Magda fait équipe avec d'autres femmes, saltimbanques de la chair et du rêve, comme elle, et ensemble elles parcourent la Terre errant de champs de bataille en ruines fumantes, avec leur spectacle de cabaret et procédant à la sélection de l'homme le plus malheureux. Mais la Mort est aussi du voyage.

L'extrait qu'on lira ici met en scène la Mort, au moment où elle se penche sur elle-même et constate la désolation qu'elle apporte, avec un mélange de fierté, de cynisme et de mélancolie: "Je suis partout partout là où ça charcle*.» Mais que peut faire la Mort contre elle-même? Chanter, peut-être!

* Charcler: terme familier du midi de la France, semble appartenir à la famille des «chair, charcuterie, charcuter». Signifie (approximativement) faire saigner, faire gicler.

\section{SCÈNE 16}

\section{LE NUMÉRO DE LA MORT}

MADEMOISELLE CHANTE,

LA HACHE À LA MAIN. LE SOLDAT RESTE ACCROCHÉ

SUR ELLE ET «COULE »

LENTEMENT VERS LE SOL.

\section{MADEMOISELLE}

La guerre des Boers

La guerre de Corée

La guerre d'Indochine

La guerre du Viet-Nam?

Me voilà, Mademoiselle!

Je suis partout partout

Là où ça charcle;

Là où ça saigne,

J'accours, je vole! je vole!

La guerre d'Algérie

La guerre de Tchétchénie

La Guinée, le Libéria

Le Zaïre et le Rwanda?

Me voilà, Mademoiselle!
Je suis partout partout

Là où ça charcle;

Là où ça saigne,

J'accours, je vole! je vole!

La Première Guerre mondiale

La Deuxième Guerre mondiale

La guerre du Liban

La guerre de sept jours

La guerre du Golfe

Et la guerre froide?

Me voilà, Mademoiselle!

Je suis partout partout

Là où ça charcle;

Là où ça saigne,

J'accours, je vole! je vole!

L'Holocauste

Les camps de Palestiniens

Le génocide des Arméniens

Le massacre des Tziganes?

Octobre rouge

La Place Tienanmen

Les purges staliniennes

Les Khmers rouges?

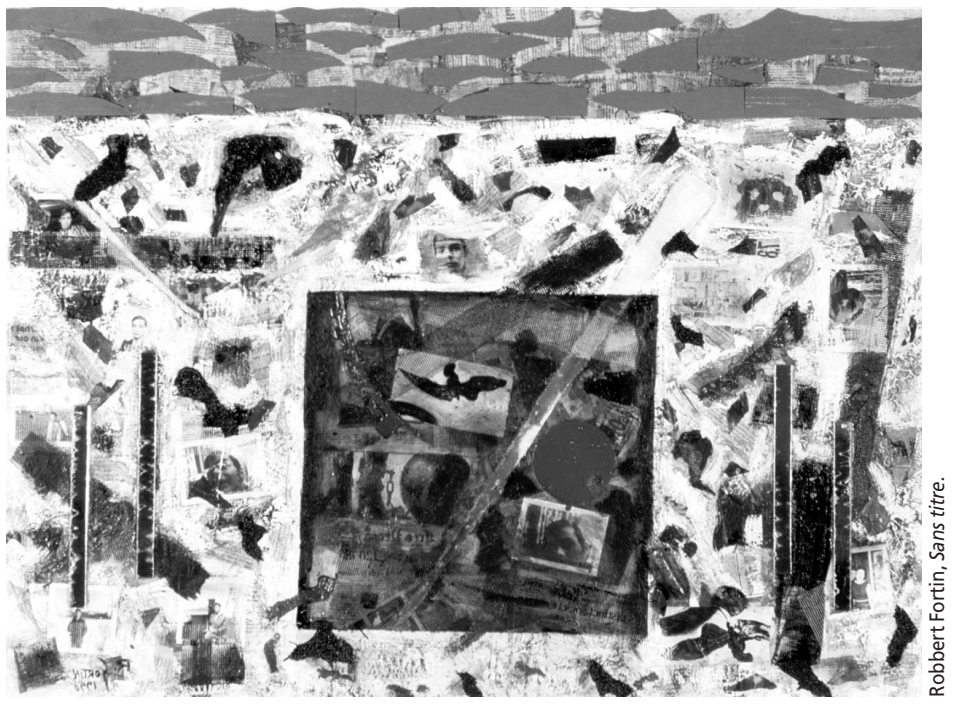

parlé

Polpot, Pinochet, Somosa

Le FIS, le G.I.A., l'Ayatollah

Mobutu, Duvallier,

Et Laurent Désiré?

L'Apartheid, le Goulag

Les petites Chinoises

Les enfants de Duplessis

Et le Général Milan?

Me voilà, Mademoiselle!

Je suis partout, partout

Là où ça charcle;

Là où ça saigne,

J'accours, je vole! je vole!

parlé

Ne m'appelez pas Madame,

j'ai trop d'amants;

Impossible d'être fidèle,

Appelez-moi Mademoiselle.

VERS LA FIN

DE LA CHANSON,

LE SOLDAT S'AFFALE

FINALEMENT SUR LE SOL.
MADEMOISELLE

ENLÈVE SON MASQUE

RETOURNE À SON ESPACE

AU MÊME MOMENT,

SISSI HURLE.

MADEMOISELLE

En-avant!

Pascale Rafie se consacre à l'écriture dramatique depuis plus de 15 ans. Elle signe des textes pour enfants (Charlotte Sicotte, Comment la terre s'est mise à tourner, Au bout de la rivière) ainsi que pour les adultes, notamment: Soleil, Le Paradis mobile, comédie candide, qu'elle met en scène et produit avec sa compagnie, le Théâtre la Caravane, en 2000. 